\title{
Pengaruh Human Relation (Hubungan Antar Manusia), Lingkungan kerja Terhadap Etos Kerja karyawan (Studi Kasus Pada PT.Pelindo Teluk Bayur Padang )
}

\author{
Boby Hendra Widodo, Febsri Susanti \\ Sekolah Tinggi Ilmu Eknomi "KBP" \\ febsrisusanti@akbpstie.ac.id
}

\begin{abstract}
This research was conducted on one of PT.Pelindo Teluk Bayur Padang. The method used in the form of survey methods through the distribution of questionnaires. Of the population of 154, using purposive sampling technique, obtained the number of samples as many as 40 people. Path analysis is used as a quantitative analysis.

The results of calculations that have been done in this study found that the human relations variable has a positive and significant effect on the physical condition of the environment at PT.Pelindo Padang. The regression coefficient is 0.941 and its significance is 0.000 which is smaller than 0.05. This can be interpreted that the variable of human relation have positive and significant effect to the environmental condition, thus, the first hypothesis (H1) in this research which states that human relation have positive and significant effect to the environmental condition of PT.Pelindo is acceptable. Based on the results of the second hypothesis testing, it was found that the variables of opportunity of work ethos had negative and insignificant effect on work environment at PT.Pelindo Padang. The regression coefficient coefficient of the work opportunity opportunity variable -2.96 and the significance of 0.141 is greater than 0.05. It can be interpreted that work ethos variable has negative and insignificant effect to work environment condition, hence second hypothesis (H2) in this research which stated that work ethos have negative and insignificant effect to physical condition of work environment at PT.Pelindo Padang, declared rejected.
\end{abstract}

Keywords: Inter-human Relations, work environment and work ethic.

\section{PENDAHULUAN}

\section{Latar Belakang Masalah}

Pada saat sekarang ini perusahaan harus memiliki orientasi yang tinggi pada perubahan skala besar. Pada yang besar ini selalu mempunyai kaitan untuk menentukan suatu strategi. Salah satu strategi yang harus di jalani yaitu untuk menentukan sdm yang mampu bekerja secara bersama.

Pada pengelolaan organisasi mempunyai kaitan yang tinggi untuk mencapai tujuannya, Hersey dan Blanchard (2000) mengatakan bahwa pengabungan tujuan dan efektivitas pada organisasi harus bisa mewujudkan tujuan yang dimiliki organisasi meski didukung oleh semua pihak dalam organisasi, inilah yang dimaksud dengan pengabungan organisasi yang memiliki tujuan yang sesungguhnya. Bahwa tujuan tersebut merupakan tujuan mereka atau tujuan bersama.

Dari penjelasan diatas dapat terlihat jelas bahwa suatu perusahaan atau organisasi dapat tercapai tujuannya dikarenakan dari aktifitas orang-orang yang menjadi anggota atau karyawannya. Mereka dapat bekerja sama dengan baik apabila mereka bekerja dengan dilandasi oleh etos kerja yang tinggi, dengan etos kerja yang tinggi ini maka tidak dipungkiri juga akan meningkatkan kinerja mereka.

Pada era ekonomi global ini 
memberikan upaya-upaya untuk terobosan para pelaku utama usaha untuk secara proaktif mengkondisikan diri dalam rangka untuk mengkuatkan keunggulan dalam bersaing, yang tidak lagi mengandalkan keunggulan komparatif dibidang bahan baku dan sumber daya manusia saja, namun juga keunggulan kompetitif dapat diraih jika pelaku bisnis mempunyai kompetensi organisasi, artinya pebisnis tersebut terdapat kenaikan dalam bekerja.

Perubahan dan persaingan yang begitu cepat melakukan upaya dan terobosan dalam perusahaan dan institusi secara proaktif dan mengkonsolidasikan diri dalam rangka penguatan dan keunggulan bersaing. Untuk dapat unggul dalam bersaing dan tetap bertahan, maka perusahaan harus adaptif dan lebih fleksibel. Hal ini sering kali menuntut perusahaan untuk melakukan perubahan dalam perusahaan itu sendiri.

Hubungan sesama karyawaan pada PT.Pelindo Cabang Padang disini kurang baik, karena karyawan masih membawa hubungan pribadi antar hubungan kerja, misalkan ada salah satu karyawan berprestasi maka ada beberapa karyawan tidak begitu senang. Lingkungan kerja juga kurang kondusif, masih ada ruangan lama dengan meja-meja lama yang belum di ganti dengan yang baru. Dan letak kantor Pelindo ini juga jauh dari kota, maka banyak karyawan yang mengeluh atas tata letak Pelindo ini, perusahaan Pelindo ini juga sering banjir apabila sudah hujan deras banyak file-file yang terendam banjir dan itu juga menyebabkan ketidak efektifan dalam bekerja.

\section{Etos Kerja}

\section{Pengertian Etos Kerja}

Setiap organisasi atau perusahaan yang selalu ingin maju, akan melibatkan anggotanya untuk meningkatkan mutu kinerjanya, diantaranya setiap organisasi harus memiliki etos kerja.

Menurut Bob Black dalam Iga Manuati Dewi (2002), kerja yaitu suatu aktivitas yang dilakukan seseorang untuk mencapai tujuan-tujuan yang ingin dipenuhinya. Etos kerja menurut Chaplin (2001) mengatakan bahwa etos kerja yaitu watak dan karakter suatu kelompok nasional atau kelompok rasial tertentu. Etos kerja dalam suatu perusahaan tidak akan muncul begitu saja, akan tetapi harus diupayakan dengan sungguh- sungguh melalui proses yang terkendali dengan melibatkan semua sumber daya manusia dalam seperangkat sistem dan alat-alat pendukung. Tasmara (2002) menyebutkan bahwa etos kerja merupakan suatu totalitas kepribadian dari individu serta cara individu mengekspresikan, memandang, meyakini dan memberikan makna terhadap suatu yang mendorong individu untuk bertindak dan meraih hasil yang optimal (high performance).

\section{Pengertian Human Relation ( Hubungan antar Manusia ) \\ Hubungan manusiawi adalah} terjemahan dari human relation. Orangorang juga ada yang menterjemahkan menjadi "hubungan manusia" atau juga diterjemahkan "hubungan antar manusia", yang sebenarnya tidak terlalu salah karena yang berhubungan satu sama lain adalah manusia. Hanya saja, disini sifat hubungan sesama manusianya tidak seperti orang berkomunikasi biasa, bukan hanya merupakan penyampaian suatu pesan oleh seseorang kepada orang lain, tetapi hubungan antara orang-orang yang berkomunikasi dimana mengandung unsur-unsur kejiwaan yang amat mendalam.

\section{Faktor-faktor Persepsi Interpersonal dalam Human Relation ( Hubungan Antar manusia )}

Persepsi kita bukan sekedar rekaman peristiwa atau objek. Komputer hanya mengolah input yang dimasukkan oleh seseorang. Pengaruh kebutuhan, kesiapan mental, suasana emosional, dan latar belakang budaya, menentukan interpretasi kita pada sensasi. Bila objek atau peristiwa didunia luar kita sebut 
distalstimuli dan persepsi kita tentang stimuliitu kita sebut persepsi ( percept) maka persepsi tidak selalu sama dengan distalstimuli.

\section{Teknik-teknik Human Relation ( Hubungan Antar Manusia )}

Hubungan manusiawi dapat dilakukan untuk menghilangkan hambatan-hambatan komunikasi, meniadakan salah pengertian dan mengembangkan segi konstruktif sifat tabiat manusia (Onong, 2001 ). Dalam derajat intensitas yang tinggi, hubungan manusiawi dilakukan untuk menyembuhkan orang yang menderita frustasi. Frustasi timbul pada diri seseorang akibat suatu masalah yang tidak dapat dipecahkan olehnya. Akan tetapi masalah yang bagaimanapun akan diusah akan supaya hilang. Orang tidak akan membiarkan dirinya dipusingkan oleh masalah. Dan masalah orang yang satu tidak sama dengan masalah orang lain.

\section{Hambatan dalam HumanRelation ( Hubungan Antar Manusia )}

Hambatan dalam hubungan antar manusia pada umumnya mempunyai dua sifat yaitu objektif dan subjektif. Hambatan yang sifatnya objektif adalah gangguan dan halangan terhadap jalannya hubungan antar manusia yang tidak disengaja dan dibuat oleh pihak lain tapi mungkin disebabkan oleh keadaan yang tidak menguntungkan. Hambatan yang bersifat subjektif adalah yang sengaja dibuat oleh orang lain sehingga merupakan gangguan, penentangan terhadap suatu usaha komunikasi.

\section{METODE PENELITIAN}

Metode Penelitian

Jenis penelitian yang digunakan dalam penelitian ini adalah penelitian Kuantitatif Penelitian ini merupakan penelitian yang bertujuan menjelaskan fenomena yang ada dengan menggunakan angka-angka untuk mencandarkan karakteristik individu atau kelompok (Syamsudin \& Damiyanti: 2011). Penelitian ini menilai sifat dari kondisikondisi yang tampak. Tujuan dalam penelitian ini dibatasi untuk menggambarkan karakteristik sesuatu sebagaimana adanya.

\section{Populasi dan Sampel}

Populasi merupakan objek atau subjek yang berada pada suatu wilayah dan memenuhi syarat-syarat tertentu berkaitan dengan masalah penelitian. Sampel merupakan bagian dari populasi data suatu penelitian diperlukan penarikan sampel, Menurut Sugiyono (2006).

Dan kriteria yang telah di tentukan oleh peneliti untuk pembagian kusioner kepada karyawan PT.Pelindo adalah ditentukan dari umur para karyawan yang akan menjadi responden pada penelitian ini yaitu, pada umur 21 tahun sampai 40 tahun dan penentuan sampel juga dilihat pada komposisi responden berdasarkan tingkat pendidikan dari responden tersebut dan tingkat pendidikan yang diambil adalah d3 dan s1. Dari kriteria yang telah ditentukan oleh peneliti maka dapatlah sampel dari penelitian ini sebanyak 40 kusioner.

\begin{tabular}{lcrr}
\multicolumn{2}{c}{ Perhitungan } & bobot & penilaian \\
kuisioner & kepuasan & karyawan \\
menggunakan & skala & likert & yang \\
menjelaskan & & &
\end{tabular}




\begin{tabular}{cc}
\hline Tingkat Kepuasan & Skor \\
\hline Sangat Puas & 5 \\
Puas & 4 \\
Cukup Puas & 3 \\
Kurang Puas & 2 \\
Sangat Tidak Puas & 1
\end{tabular}

\section{Teknik Pengumpulan Data}

Teknik pengumpulan data yang digunakan adalah sebagai berikut ini.

a. Observasi (pengamatan langsung)

Penulis mengadakan pengamatan secara langsung terhadap objek yang diteliti dalam hal ini adalah karyawan PT.Pelindo Cabang Padang.

b. Metode kuesioner

Suatu cara yang di lakukan oleh peneliti untuk mendapat hasil penelitian, kuisioner ini berupa pertanyaan yang akan di sebarkan kepada karyawan yang sedang bekerja di PT.Pelindo.

\section{Variabel Terikat atau Dependen Variabel (Y)}

Etos Kerja

Etos kerja adalah watak atau karakter suatu kelompok nasional atau kelompok rasial tertentu. Etos kerja dalam suatu perusahaan tidak akan muncul begitu saja, akan tetapi harus diupayakan dengan sungguh- sungguh melalui proses yang terkendali dengan melibatkan semua sumber daya manusia dalam seperangkat sistem dan alat-alat pendukung.

\section{Variabel Bebas atau Independen} Variabel (X)

\section{a. Human Relation ( Hubungan Antar Manusia )}

Human relation (hubungan antar manusia ) merupakan syarat utama untuk keberhasilan suatu komunikasi baik komunikasi antar perorangan maupun komunikasi dalam instansi atau perusahaan. Penguasaan dalam menciptakan human relation karyawan dalam perusahaan atau instansi akan sangat membantu seorang pimpinan dalam membantu komunikas ivertikal maupun komunikasi horisontal.

\section{Lingkungan Kerja}

Lingkungan tempat kerja yang dapat mempengaruhi atau meningkatkan efisiensi kerja antara lain: tata ruang kerja yang tepat,cahaya dalam ruangan yang tepat, suhu dan kelembaban udara yang tepat, suara yang tidak mengganggu konsentrasi kerja.

\section{Teknik Analisis Data} Uji Validitas

Validitas yaitu suatu ukuran yang menunjukkan tingkat kevalidan atau kesahan suatu instrumen (Arikunto). Sebuah instrumen dikatakan valid apabila mampu mengukur apa yang diinginkan dan dapat mengungkap data dari variabel yang diteliti secara tepat. Instrumen atau pertanyaan dikatakan valid jika mempunyai koefisein korelasi ( $\mathrm{r}$ hitung) $\geq$ 0,3 (sugiyono, 2004). Alat pengujian yang digunakan adalah Pearson Correlation dengan bantuan komputer program SPSS 16.0 .

\section{Uji Reliabilitas}

Uji reliabilitas digunakan untuk mengukur apakah jawaban responden terhadap kuesioner adalah konsisten atau stabil dari waktu ke waktu (Ghozali 2011). Besarnya koefisien alpha yang diperoleh menunjukkan koefisien reliabilitas instrumen. Reliabilitas instrumen penelitian dalam penelitian ini diuji dengan menggunakan koefisien Cronbachs Alpha. Jika nilai koefisien alpha lebih 
besar dari 0,6 maka disimpulkan bahwa instrumen penelitian tersebut handal dan reliabel (Ghozali, 2011).

\section{Uji TCR (Tingkat Capaian Responden)}

Menurut Suharsimi (2002) total capaian responden merupakan suatu ukuran untuk menghitung masing-masing kategori jawaban dari deskriptif variabel, maka dapat dihitung dengan menggunkan rumusan:

$$
T C R=\frac{\text { Skor tiap item }}{\text { Skor ideal item yang dihitung }} \times 100 \%
$$

Keterangan:

TCR $=$ Tingkat Capaian Responden

Untuk menginterprestasikan jawaban responden terhadap pertanyaa yang diajukan, sebagai acuannya tabel kriteria pengklasifikasikan rata-rata jawaban responden sebagai berikut:

1. $81-100 \%=$ sangat baik

2. $61-80 \%=$ baik

3. $41-60 \%=$ kurang baik

4. $21-40 \%=$ tidak baik

5. $<20 \%=$ sangat tidak baik

\section{Uji Asumsi Klasik}

Uji asumsi klasik yang digunakan meliputi uji normalitas, uji multikolinieritas, dan uji heteroskedastisitas.

\section{Uji Normalitas}

Uji normalitas bertujuan untuk mengetahui data dalam keadaan normal atau tidak, maka akan dilakukan dengan metode Kolmogorov Smirnov dengan alat bantu SPSS. Distribusi data dikatakan normal apabila nilai Asymp significance lebih besar dari 0,05 (Ghozali, 2013).

Indikator yang digunakan Uji kolmogrovsmirnov dengan pedoman yaitu :

a. Jika nilai signifikansi > 0,05.,maka berdistribusi normal

b. Jika nilai signifikans < 0,05.,maka tidak berdistribusi normal

\section{Uji Multikolinieritas}

Uji multikolonieritas bertujuan untuk menguji apakah pada model regresi ditemukan adanya korelasi antar variabel independen. Jika terjadi korelasi, maka dinamakan terdapat problem (multiko). Model regresi yang baik seharusnya tidak terjadi korelasi di antara variabel independen. Untuk mendeteksi adanya problem multiko, maka dapat dilakukan dengan melihat nilai Tolerance dan Variance Inflation Factor (VIF) serta besaran korelasi antar variabel independen.

\section{Uji Heteroskedastisitas}

Uji heteroskedastisitas bertujuan menguji apakah dalam model regresi terjadi ketidak samaan variance dari residual satu pengamatan kepengamatan yang lain. Jika variance dari residual satu pengamatan kepengamatan lain tetap, maka disebut homoskedastisitas dan jika berbeda disebut heteroskedastisitas.

\section{Analisis Regresi Berganda}

Analisis regresi berganda untuk mengetahui apakah variabel independen berpengaruh atau tidak terhadap variabel dependen, maka dapat dilihat dari taraf signifikansinya dengan standar signifikansi 5\%. Apabila tingkat signifikansi yang diperoleh dari hasil lebih besar dari 5\% maka hipotesis ditolak, sebaliknya jika hasil uji hipotesis berada diantara 0-5\% maka hipotesis diterima.

\section{Uji Hipotesis}

\section{Uji T}

Menurut Imam Ghozali (2011) uji statistik $\mathrm{t}$ pada dasarnya menunjukkan seberapa jauh pengaruh satu variabel independen secara individual dalam menerangkan variabel dependen. Pengujian dilakukan dengan menggunakan signifikan level $0,05(\alpha=5 \%)$.

\section{Uji $\mathbf{R}^{2}$}

Koefisien determinasi pada intinya mengukur seberapa jauh kemampuan model dalam menerangkan variasi variabel dependen. Nilai koefisien determinasi adalah antara nol dan satu. Nilai R2 yang kecil berarti kemampuan variabel-variabel 
independen dalam menjelaskan variasi variabel dependen sangat terbatas.

\section{Uji Statistik F}

Uji Statistik F pada dasarnya menunjukkan apakah semua variable independen yang dimasukkan dalam model mempunyai pengaruh secara bersamasama terhadap variabel dependen. Uji $F$ dapat dilakukan dengan melihat nilai $\mathrm{F}$ lebih besar dari 4 maka Ho dapat ditolak pada derajat kepercayaan $5 \%$.

\section{ANALISIS DATA DAN \\ PEMBAHASAN}

\section{Sejarah PT.Pelabuhan Indonesia II (Persero)}

Indonesia merupakan Negara kepulauan yang dua pertiga wilayahnya adalah perairan dan terletak pada lokasi yang strategis karena berada di persilangan rute perdagangan dunia. Sehingga peran pelabuhan dalam mendukung pertumbuhan ekonomi maupun mobilitas sosial dan perdagangan di wilayah ini sangat besar. Oleh karenanya pelabuhan menjadi faktor penting bagi pemerintah dalam menjalankan roda perekonomian Negara. PT. Pelabuhan Indonesia II (Persero) merupakan salah satu badan usaha milik negara yang diposisikan untuk mendukung

Tabel 4.1

Komposisi Responden Berdasarkan Jenis Kelamin

\begin{tabular}{ccc}
\hline Jenis Kelamin & Frekuensi & Presentasi (\%) \\
\hline Laki-Laki & $\mathbf{2 2}$ & $\mathbf{5 5}$ \\
Perempuan & 18 & 45 \\
Jumlah & 40 & 100 \\
\hline
\end{tabular}

Sumber: data primer yang diolah,2017

Dari tabel diatas dapat disimpulkan bahwa yang menjadi responden dalam penelitian ini lebih banyak karyawan lakilaki dari pada karyawan perempuan. Hal ini disebabkan karena banyaknya pekerjaan yang memerlukan tenaga atau menggunakan fisik.

\section{Komposisi Responden Menurut Umur}

Umur seseorang dapat

mempengaruhi kinerja atau produktivitas kerja dari orang tersebut. Kinerja kebijakan pemerintah dan program pembangunan nasional, ekonomi serta untuk mencari keuntungan dengan menyediakan pelayanan jasa kepelabuhan dan aktivitas bisnis lainnya.

\section{Komposisi Responden Menurut Jenis Kelamin}

Jenis kelamin disini merupakan faktor genetis yang dapat mempengaruhi kinerja karyawan. Pada umumnya semangat kerja maupun kinerja orang yang mempunyai jenis kelamin laki-laki dan wanita itu tidaklah sama dalam objek pekerjaan tertentu. Tetapi secara psikologis wanita lebi teliti dan sabar menyelesaikan satu pekerjaan. Penelitian ini di tunjukan pada karyawan perusahaan dagang, dimana dibutuhkan ketelitian, kesabaran, dan kerjasama yang baik didalam melaksanakan pekerjaan.

Deskripsi tentang jenis kelamin responden dapat dilihat tabel 4.1 di bawah ini: karyawan dapat ditentukan dari umur. Pada umumnya, semakin tua seseorang maka tingkat kinerja pun akan menurun, tetapi hal ini biasanya diimbangi dengan pengalaman kerja yang dimiliki akan semakin meningkat.

Untuk mengetahui gambaran umur tentang responden dapat dilihat pada tabel 4.2 dibawah ini: 
Tabel 4.2

Komposisi Responden Berdasarkan Umur

\begin{tabular}{ccc}
\hline Umur & Jumlah & Persentase ( \% ) \\
\hline $21-30$ Tahun & 21 & 52,5 \\
$31-40$ Tahun & 19 & 47,5 \\
Jumlah & 40 & 100 \\
\hline
\end{tabular}

Sumber: data primer yang diolah, 2017

Data tabel diatas dapat disimpulkan bahwa yang menjadi responden dalam penelitian ini lebih banyak karyawana yang berumur 21 tahun sampai dengan 30 tahun. Hal ini dikarenakan usia $21-30$ tahun masih produktif dan memiliki daya tahan kerja yang masih tinggi.

\section{Komposisi Responden Menurut Tingkat Pendidikan}

Respon dalam penelitian ini memiliki keragaman tingkat pendidikan, dimana tingkat pendidikan juga berpengaruh terhadap kinerja karyawan dalam melaksanakan pekerjaan yang ditetapkan kepadanya.

Deskripsi responden tentang tingkat pendidikan dapat dilihat pada tabel 4.3 dibawah ini :

Tabel 4.3

Komposisi Responden Berdasarkan Tingkat Pendidikan

\begin{tabular}{ccc}
\hline Pendidikan & Jumlah & Presentase ( \% ) \\
\hline D3 & 15 & 37,5 \\
S1 & 25 & 62,5 \\
Jumlah & 40 & 100 \\
\hline
\end{tabular}

Sumber : data primer yang diolah, 2017

Dari tabel diatas dapat disimpulakan bahwa yang menjadi responden dalam penelitian ini lebih banyak karyawan yang memiliki tingkat pendidikan S1. Hal ini dikarenakan jenis pekerjaan yang ditawarkan oleh perusahaan tingkat pendidikan yang tinggi.

\section{Analisis Data \\ Uji Validitas}

Uji validitas digunakan untuk melihat ketepatan suatu instrumen yang digunakan. Metode yang digunakan untuk menguji validitas kali ini adalah Corrected Item-Total Correlation. Untuk menguji validitas setiap butir maka skor-skor yang ada pada butir yang dimaksud dikorelasikan dengan skor total.

Kriteria pegujian adalah :

1. Apabila nilai Corrected Item-Total Correlation $\geq 0,3$ maka instrument atau item-item peranyataan dinyatakan valid.

2. Apabila nilai $\mathrm{r}$ hitung (nilai Corrected Item-Total Correlation) < 0,3 maka instrument atau item-item pernyataan dinyatakan tidak valid.

\section{Human Relation}

Hasil uji validitas untuk variabel independen yaitu Human Relation (X1) disajikan dalam table 4.4 berikut: 
Tabel 4.4

Hasil Uji Validitas Human Relation (X1)

\begin{tabular}{cccc}
\hline $\begin{array}{c}\text { Butir } \\
\text { Pertanyaan }\end{array}$ & R hitung & R tabel & Kesimpulan \\
\hline HR1 & 0,593 & 0,30 & Valid \\
HR2 & 0,525 & 0,30 & Valid \\
HR3 & 0,525 & 0,30 & Valid \\
HR4 & 0,652 & 0,30 & Valid \\
HR5 & 0,652 & 0,30 & Valid \\
HR6 & 0,617 & 0,30 & Valid \\
\hline
\end{tabular}

Sumber Data diolah dengan SPSS 16

Berdasarkan hasil dari perhitungan uji validitas variabel X1 (Human Relation) terhadap 40 responden, didapatkan bahwa semua butir pernyataan dinyatakan valid. Hal ini ditunjukkan dengan nilai Corrected Item-Total Correlation yang lebih besar dari 0,30, sehingga dapat dilakukan untuk penelitian lebih lanjut.

\section{Etos Kerja}

Hasil uji validitas untuk variabel independen yaitu Etos Kerja disajikan dalam table 4.6 berikut:

Tabel 4.6

Hasil Uji Validitas Lingkungan Kerja (X2)

\begin{tabular}{cccc}
\hline $\begin{array}{c}\text { Butir } \\
\text { Pertanyaan }\end{array}$ & R hitung & R tabel & Kesimpulan \\
\hline LK1 & 0,607 & 0,30 & Valid \\
LK2 & 0,337 & 0,30 & Valid \\
LK3 & 0,598 & 0,30 & Valid \\
LK4 & 0,650 & 0,30 & Valid \\
LK5 & 0,607 & 0,30 & Valid \\
LK6 & 0,339 & 0,30 & Valid \\
\hline
\end{tabular}

Sumber Data diolah dengan SPSS 16

Berdasarkan hasil dari perhitungan uji validitas variabel X2 (Lingkungan Kerja) terhadap 40 responden, didapatkan bahwa semua butir pernyataan dinyatakan valid. Hal ini ditunjukkan dengan nilai Corrected Item-Total Correlation yang lebih besar dari 0,30, sehingga dapat dilakukan untuk penelitian lebih lanjut.

\section{Hasil Uji \\ Tabel 4.5}

Hasil Uji Validitas Etos Kerja (Y)

\begin{tabular}{cccc}
\hline $\begin{array}{c}\text { Butir } \\
\text { Pertanyaan }\end{array}$ & R hitung & R tabel & Kesimpulan \\
\hline EK1 & 0,549 & 0,30 & Valid \\
EK2 & 0,728 & 0,30 & Valid \\
EK3 & 0,728 & 0,30 & Valid \\
EK4 & 0,637 & 0,30 & Valid \\
EK5 & 0,549 & 0,30 & Valid \\
EK6 & 0,520 & 0,30 & Valid \\
\hline
\end{tabular}

Sumber Data diolah dengan SPSS 16

Berdasarkan hasil dari perhitungan uji validitas variabel X2 (Etos Kerja) terhadap 40 responden, didapatkan bahwa semua butir pernyataan dinyatakan valid. Hal ini ditunjukkan dengan nilai Corrected Item-Total Correlation yang lebih besar 
dari 0,30 , sehingga dapat dilakukan untuk penelitian lebih lanjut. karyawan, etos kerja berikut tabel uji reabilitas.

\section{Uji Reabilitas}

Hasil uji reabilitas untuk setiap human relation, lingkungan kerja

Tabel 4.7

Hasil Uji Reabilitas

\begin{tabular}{llll}
\hline No & Variabel & Cronbach`s Alpha & Keterangan \\
\hline 1 & Human Relation & 0,767 & Reliabel \\
2 & Lingkungan Kerja & 0,747 & Reliabel \\
3 & Etos Kerja & 0,771 & Reliabel \\
\hline
\end{tabular}

Sumber data diolah SPSS 16

Dari tabel 4.7 dapat dilihat variabel Human Relation, Lingkungan Kerja, Etos Kerja di kategorikan reabel. Hal ini dikarenakan nilai Cronbach's Alpha yang dihasilkan untuk setiap variabel lebih besar dari 0,600. Sehingga butir pertanyaan untuk variabel Human Relation, Lingkungan Kerja, Etos Kerja termasuk reabel dapat digunakan sebagai alat ukur dalam penelitian.

\section{Uji Asumsi Klasik}

Uji Normalitas

Uji Normalitas dilakukan untuk menguji apakah dalam sebuah model regresi variabel independen dan variabel dependenmemiliki ditribusi normal atau tidak. Data dikatakan berdistribusi normal apabila Asymp Sig ( 2-tailed )lebih besar dari level of significant yang dipakai yaitu 0,05 .

Tabel 4.11

Hasil Uji Normalitas

\begin{tabular}{|c|c|c|}
\hline \multicolumn{3}{|c|}{ One-Sample Kolmogorov-Smirnov Test } \\
\hline & & Standardized Residual \\
\hline \multicolumn{2}{|l|}{$\mathrm{N}$} & 40 \\
\hline \multirow{2}{*}{ Normal Parameters ${ }^{\mathrm{a}} \mathrm{I}$} & Mean & .0000000 \\
\hline & Std. Deviation & .97402153 \\
\hline \multirow{3}{*}{$\begin{array}{l}\text { Most Extreme } \\
\text { Differences }\end{array}$} & Absolute & .082 \\
\hline & Positive & .042 \\
\hline & Negative & -.082 \\
\hline \multicolumn{2}{|c|}{ Kolmogorov-Smirnov Z } & .516 \\
\hline \multicolumn{2}{|l|}{ Asy mp. Sig. (2-tailed) } & .953 \\
\hline
\end{tabular}

Pada tabel 4.11 berdasarkan pada output diatas terlihat bahwa nilai sig sebesar $0,953>0,05$. Hal ini dapat disimpulkan bahwa data berdistribusi normal.

\section{Multikolinieritas}

Uji ini digunakan untuk melihat ada atau tidak hubungan (korelasi) antara sesama variabel bebas. Pengujian ini dilakukan dengan menggunakan metode uji VIF (Variance Inflation Factor), dalam pengujian VIF menggunakan criteria pengujian apabila nilai $\mathrm{VIF}<10$, maka dapat dikatakan tidak terjadi masalah multikonearitas dan nilai toleransinya > 0,1 maka tidak terjadi masalah multikonearitas. Berikut hasil Uji 
Multikonearitas dapat dilihat pada tabel 4.12.:

Tabel.12

\section{Hasil Uji Standar Error Uji Multikolinearitas}

\begin{tabular}{|c|c|c|c|c|c|c|c|c|}
\hline \multicolumn{9}{|c|}{ Coefficients $^{\mathrm{a}}$} \\
\hline \multirow[b]{2}{*}{ Model } & & \multicolumn{2}{|c|}{$\begin{array}{l}\text { Unstandardized } \\
\text { Coefficients }\end{array}$} & \multirow{2}{*}{$\begin{array}{c}\text { Standardized } \\
\text { Coefficients }\end{array}$} & \multirow[b]{2}{*}{$\mathrm{T}$} & \multirow[b]{2}{*}{ Sig. } & \multicolumn{2}{|c|}{$\begin{array}{c}\text { Collinearity } \\
\text { Statistics }\end{array}$} \\
\hline & & $\mathrm{B}$ & Std. Error & & & & Tolerance & VIF \\
\hline \multirow[t]{3}{*}{1} & (Constant) & 3.233 & 2.318 & & 1.395 & .171 & & \\
\hline & $\begin{array}{l}\mathrm{hr}: \text { human } \\
\text { relation }\end{array}$ & 1.010 & .122 & .988 & 8.304 & .000 & .475 & 2.107 \\
\hline & $\begin{array}{l}\text { lk: } \\
\text { lingkungan } \\
\text { kerja }\end{array}$ & -.195 & .129 & -.179 & -1.504 & .141 & .475 & 2.107 \\
\hline
\end{tabular}

Sumber data diolah dengan SPSS 16

Berdasarkan uji multikonearitas bahwa menunjukkan nilai tolerance dari setiap variabel bebas $0,475>0,1$ dan nilai VIF $2.107<10$, maka kesimpulannya tidak terjadi masalah multikonearitas.

\section{Uji Heteroskedastisitas}

Dalam uji heteroskedastisitas dilakukan untuk mengetahui apakah terjadi ketidaksamaan varians dari residual ke pengamatan yang lain. Model regresi yang memnuhi persyaratan baik adalah apabila tidak terjadi masalah heteroskedatisitas. Pengujian ini digunakan dengan menggunakan metode grafik plot. Apabila plot membentuk pola tertentu, maka terjadi masalah heteroskedatisitas, tetapi jika plot menyebar dan tidak membentuk suatu pola maka tidak terjadi masalah heteroskedatisitas. Berikut hasil uji heteroskedatisitas menggunakan metode grafik, dapat dilihat pada tabel 4.12.

Tabel.13

Uji heteroskedastisitas

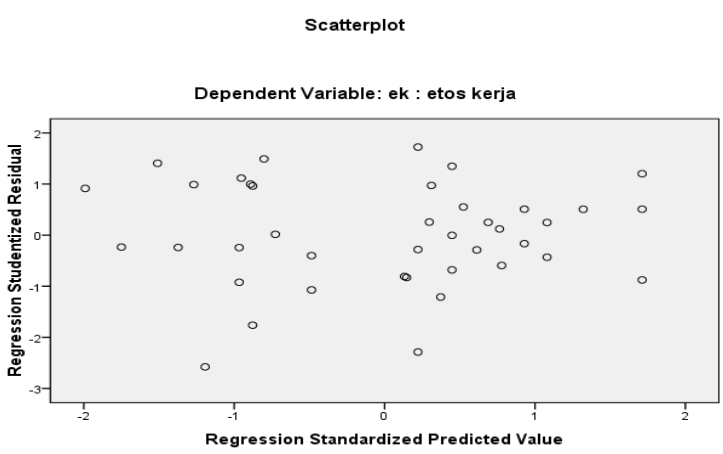

Sumber: data di olah dengan SPSS 16

Dari grafik diatas terlihat bahwa plot menyebar secara tidak teratur atau tidak teratur atau tidak berpola sehingga dapat disimpulkan bahwa mode regresi tidak mengandung masalah heteroritas.
Analisis Regresi Linear Berganda

Analisis regresi linear berganda digunakan untuk mengukur kekuatan hubungan antara dua variabel atau lebih, dan juga menunjukkan arah hubungan 
antara variabel dependen dengan variabel independen. Hasil analisis regresi

Tabel 4.13

Hasil Uji Regresi Linear Berganda

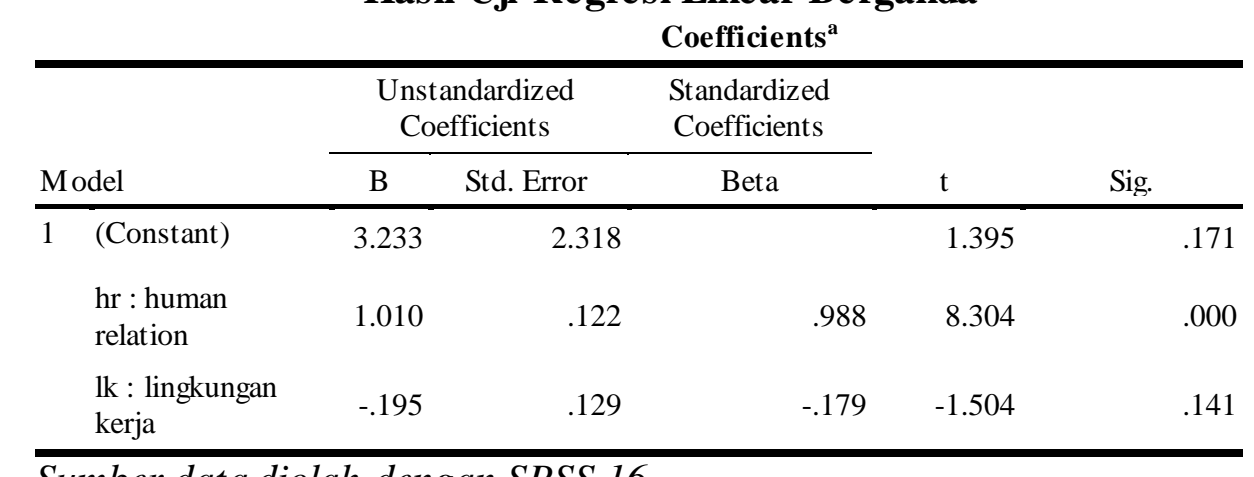

Sumber data diolah dengan SPSS 16

Berdasarkan hasil regresi yang didapat maka dibuat persamaan linear berganda sebagai berikut :

$$
\mathrm{Y}=0,3233+0,101 \mathrm{X} 1-1,95 \mathrm{X} 2
$$

Persamaan regresi linear berganda diatas mempunyai arti sebagai berikut :

1. Konstanta mempunyai nilai positif sebesar 0.3233. hal ini berarti apabila human realation dan lingkungan kerja pada PT.Pelindo padang bernilai 0, maka etos kerja karyawan masih bernilai tetap 0,3233 .

2. Koefesien regresi $\mathrm{x} 1$ adalah positif 0,101 artinya setiap kenaikan variabel hubungan antar manusia akan meningkatkan etos kerja karyawan.

3. Koefesien regresi $\mathrm{x} 2$ adalah $-1,95$ artinya setiap penurunan variabel berganda yang diolah dengan SPSS dapat dilihat pada tabel 4.13. kondisi lingkungan kerja akan menurunkan etos kerja karyawan.

\section{Uji Hipotesis}

\section{Uji T}

Uji statistik $t$ pada dasarnya menunjukkan seberapa jauh pengaruh satu variabel penjelas atau independen secara individual dalam menerangkan variasi variabel dependen (Ghozali, 2011). Untuk menguji pengaruh masingmasing variabel bebas yang digunakan dalam penelitian ini secara parsial digunakan uji $\mathrm{t}$ dengan tingkat signifikansi 5\%. Pada uji $t$, nilai $t$ hitung akan dibandingkan dengan nilai $\mathrm{t}$ tabel, apabila nilai $\mathrm{t}$ hitung lebih besar dari t tabel maka Ha diterima dan Ho ditolak. Namun, jika nilai $\mathrm{t}$ hitung lebih kecil dari $\mathrm{t}$ tabel maka Ha ditolak dan Ho diterima.

Dilihat pada tabel berikut:

Tabel.4.13

Hasil Uji T

Coefficients $^{\mathrm{a}}$

\begin{tabular}{|c|c|c|c|c|c|c|}
\hline \multirow{2}{*}{\multicolumn{2}{|c|}{ Model }} & \multicolumn{2}{|c|}{$\begin{array}{l}\text { Unstandardized } \\
\text { Coefficients }\end{array}$} & \multirow{2}{*}{$\begin{array}{c}\text { Standardized } \\
\text { Coefficients }\end{array}$} & \multirow[b]{2}{*}{$\mathrm{t}$} & \multirow[b]{2}{*}{ Sig. } \\
\hline & & B & Std. Error & & & \\
\hline \multirow[t]{3}{*}{1} & (Constant) & 3.233 & 2.318 & & 1.395 & .171 \\
\hline & $\begin{array}{l}\mathrm{hr}: \text { human } \\
\text { relation }\end{array}$ & 1.010 & .122 & .988 & 8.304 & .000 \\
\hline & $\begin{array}{l}\text { lk: lingkungan } \\
\text { kerja }\end{array}$ & -.195 & .129 & -.179 & -1.504 & .141 \\
\hline
\end{tabular}

Sumber data diolah dengan SPSS 16 


\section{Uji F}

Uji Statistik F pada dasarnya menunjukkan apakah semua variable independen yang dimasukkan dalam model mempunyai pengaruh secara bersamasama terhadap variabel dependen. Uji $F$ dapat dilakukan dengan melihat nilai $F$ lebih besar dari 4 maka Ho dapat ditolak pada derajat kepercayaan 5\%, dengan kata lain menerima hipotesis alternatif, yang menyatakan bahwa semua variable independen secara serentak dan signifikan mempengaruhi variabel dependen.

Tabel.4.14

Hasil Uji F

ANOVA $^{\mathrm{b}}$

\begin{tabular}{lrrrrr}
\hline Model & Sum of Squares & Df & Mean Square & F & \multicolumn{1}{c}{ Sig. } \\
\hline 1 Regression & 161.208 & 2 & 80.604 & 22.872 & $.000^{\mathrm{a}}$ \\
Residual & 130.392 & 37 & 3.524 & & \\
Total & 291.600 & 39 & & & \\
\hline
\end{tabular}

Sumber data diolah dengan SPSS 16

Dari tabel 4.14 diketahui hasil uji $\mathrm{f}$ sebesar 22.872 dan nilai signifikan sebesar 0,05 . Hal ini berarti nilai signifikan f lebih kecil dari 0,05 ini menunukkan ada pengaruh signifikan antara human relation dan kesempatan terhadap turnover intention, Sehingga hipotesis yang menyatakan bahwa human relation dan etos kerja secara bersama-sama

Tabel.4.15

\section{Hasil Uji $\mathbf{R}^{2}$}

Model Summary

\begin{tabular}{lrrrr}
\hline Model & R & \multicolumn{1}{c}{ R Square } & Adjusted R Square & \multicolumn{2}{c}{ Std. Error of the Estimate } \\
\hline 1 & $.744^{\mathrm{a}}$ & .553 & .529 & 1.87726 \\
\hline
\end{tabular}

Sumber data diolah dengan SPSS 16

Besarnya koefisien determinasi dapat dilihat pada $R$ Square adalah sebesar 0,529 , yang mempunyai arti bahwa kondisi fisik lingkungan dijelaskan oleh variabel human relation dan etos kerja sebesar $55 \%$, sedangkan sebesar $45 \%$ dijelaskan oleh variabel lain yang tidak diteliti dalam penelitian ini contohnya variabel kepuasan kerja. berpengaruh terhadap lingkungan kerja dapat diterima.

\section{Uji $\mathbf{R}^{2}$}

Hasil koefisien determinasi $\left(\mathrm{R}^{2}\right)$ pengaruh human relation dan etos kerja terhadap kondisi fisik lungkungan dikemukakan pada tabel 4.15. 
Berdasarkan hasil pengujian hipotesis pertama, ditemukan bahwa variabel human relation berpengaruh positif dan signifikan terhadap etos kerja pada PT.Pelindo Padang. Besaran koefisien regresi variabel human relation 0,1010 dan signifikansinya sebesar 0,000 yang lebih kecil dari 0,05. Hal ini dapat diartikan bahwa variabel human relation berpengaruh positif dan signifikan terhadap etos kerja, dengan demikian, hipotesis pertama (H1) dalam penelitian ini yang menyatakan bahwa human relation berpengaruh positif dan signifikan terhadap etos kerja pada PT.Pelindo, dinyatakan dapat diterima.

2. Pengaruh lingkungan Kerja terhadap etos kerja pada PT.Pelindo

Berdasarkan hasil pengujian hipotesis kedua, ditemukan bahwa variabel kesempatan etos kerja berpengaruh negatif dan tidak signifikan terhadap lingkungan kerja pada PT.Pelindo Padang. Besaran koefisien regresi variabel kesempatan etos kerja -2,96 dan signifikansinya sebesar 0,141 yang lebih besar dari 0,05 . Hal ini dapat diartikan bahwa variabel etos kerja berpengaruh negatif dan tidak signifikan terhadap kondisi lingkungan kerja, dengan demikian, hipotesis kedua $(\mathrm{H} 2)$ dalam penelitian ini yang menyatakan bahwa etos kerja berpengaruh negatif dan tidak signifikan terhadap kondisi fisik lingkungan kerja pada PT.Pelindo Padang, dinyatakan ditolak.

Dengan ini dapat terlihat bahwa di dalam perusahaan tersebut para karyawan kurang memunculkan totalitas kepribadian untuk mengekspresikan, memandang, meyakini dan memberikan makna terhadap suatu yang mendorong individu untuk bertindak dan meraih hasil yang optimal ( high performance ) atau tidak dapat memunculkan etos kerja di dalam pribadi masing-masing karyawan (Tasmara,2002). Dengan mereka menerima kondisi lingkungan yang sudah disediakan perusahaan khususnya pewarnaan dalam ruang kerja maka mereka kurang bisa mengekspresikan dan memberikan suatu hasil kerja yang optimal, hal ini yang menyebabkan etos kerja dapat terwujud.

\section{Kesimpulan}

Berdasarkan hasil pengujian hipotesis pertama, ditemukan bahwa variabel human relation berpengaruh positif dan signifikan terhadap etos kerja pada PT.Pelindo Padang. Dengan demikian dapat disimpulkan hipotesis pertama diterima.

Berdasarkan hasil pengujian hipotesis kedua, ditemukan bahwa variabel kesempatan etos kerja berpengaruh negatif dan tidak signifikan terhadap lingkungan kerja pada PT.Pelindo Padang. Dengan demikian dapat disimpulkan hipotesis pertama ditolak.

\section{UCAPAN TERIMAKASIH}

Dalam penyusunan penelitian ini, penulis menyadari bahwa tanpa bimbingan dan bantuan dari berbagai pihak, penulis belum tentu dapat menyelesaikan penelitian ini. Untuk itu ucapan terimakasih yang sebesar-besarnya penulis sampaikan kepada: Bapak Febryandhie Ananda, SE, M.Si selaku ketua STIE "KBP" Padang yang telah memberikan bimbingan dan fasilitas selama penulis menjadi mahasiswi. Ibu Lidya Martha, SE, MM selaku wakil ketua dan sekaligus penasihat akademik angkatan 2013. Ibu Febsri Susanti, SEI, MM selaku ketua program studi manajemen Sekolah Tinggi Ilmu Ekonomi "Keuangan, Perbankan dan Pembangunan" Padang. Ibu Febsri Susanti, SEI, MM selaku Dosen Pembimbing penulis, yang telah membimbing penulis dari awal skripsi sampai saat sekarang ini, membimbing penulis dengan penuh kesabaran, terimakasih atas segala kesempatan yang Ibu berikan semoga nasehat-nasehat yang Ibu berikan member manfaat bagi saya selamanya. 


\section{DAFTAR PUSTAKA}

Alo liliweri. 1997. Komunikasi AntarPribadi, Bandung: Citra Aditya Bakti.

Chaplin, J.P.. 2011. Kamus Lengkap Psikologi. Jakarta: Rajagrafindo Persada.

Ferdinand. 2006. Metode Penelitian Manajemen: Pedoman Penelitian untuk skripsi, Tesis dan Disertai Ilmu Manajemen. Semarang: Universitas Diponegoro.

Ghozali, Imam. 2005. Aplikasi Analisis Multivariate dengan Program SPSS. Badan Penerbit Universitas Diponegoro. Semarang.

Handoko, T. Hani. 1995. Manajemen. BPFE: Yogyakarta.

Keith, Davis, Jhon W. Newstrom, 1995. Perilaku Dalam Organisasi, Edisi Ketujuh, Erlangga, Jakarta.

Marlius, D. (2016). Pengaruh Bauran Pemasaran Jasa Terhadap Minat Nasabah Dalam Menabung Pada Bank Nagari Cabang Muaralabuh. https://doi.org/10.31227/osf.io/vdqg $\mathrm{x}$

Nurul Rohana. 2014. "Pengaruh Kemampuan, Motivasi, Dan Lingkungan Kerja Terhadap Kinerja Karyawan (Studi Pada Bmt Taruna Sejahtera)". Skripsi. Salatiga: Program Studi Perbankan Syariah, Sekolah Tinggi Agama Islam Negeri (Stain) Salatiga.

Nur Indriantoro, M.Sc., Akuntan, Drs. Bambang Supomo, M.Si. Akuntan, 2002. Metedologi Penelitian Bisnis. Yogyakarta : Edisi Pertama, Penerbit BPFE.
Sarwoto, 1991. Dasar-dasar Organisasi dan Manajemen. Jakarta : Ghalia Indonesia

Sinamora.2005. Etos Kerja Profesional. Jakarta;PT.Spiirit Mahardika, Aoraga,Panji 2007. Jakarta

Subroto. 2005. Pengaruh Pelatihan, Motivasi dan Lingkungan Kerja Terhadap Kinerja Pegawai Dinas Peternakan dan Perikanan Kabupaten Semarang. Thesis, Surakarta : Program Pascasarjana Magister Manajemen UMS.

Sugiyono. 2006. Metode Penelitian Kuantitatif, Kualitatif dan $R$ \& D.Bandung:Alfabeta.

Susanti, F. W Ekazaputri. (2018). Service Performance Dan Kepuasan Sebagai Moderating Variabel Terhadap Loyalitas Nasabah Pada PT BPR Labuh Gunung Payakumbuh. Jurnal Benefita: Ekonomi Pembangunan Manajemen Bisnis Dan Akuntansi. Volume 3. No. 3. Hal. 433-444. http://doi.org/10.22216/jbe.v3i3.347 2

Syamsuddin,Lukman. 2011.Manajemen Keuangan .Salemba Rajawali Pers. Jakarta.

Tasmara, Membudayakan Etos kerja Islami, (Gema Insani, 2004). Aji, Gunawan dan Arifin Sabeni, "Pengaruh Etika Kerja Islam Terhadap Komitmen Organisasi Dengan Komitmen Profesi Sebagai Variabel Intervening". Simposium Nasional Akuntansi VI. Oktober 2003.

Umar, Husein, 2002, Riset Pemasaran dan Perilaku Konsumen, Penerbit PT. Gramedia Pustaka Utama, Jakarta. 